\title{
METHODOLOGICAL APPROACHES OF FORMING THE READINESS OF FUTURE ECONOMIC PROFILE'S ENGINEERS-TEACHERS FOR PROFESSIONAL ACTIVITY
}

\author{
МЕТОДОЛОГІЧНІ ПІДХОДИ ФОРМУВАННЯ ГОТОВНОСТІ \\ МАЙБУТНІХ ІНЖЕНЕРІВ-ПЕДАГОГІВ ЕКОНОМІЧНОГО ПРОФІЛЮ ДО \\ Oleksandra DUDUKALOVA, \\ Postgraduate Student \\ ПРОФЕСІЙНОЇ ДІЯЛЬНОСТІ \\ https://orcid.org/0000-0002-9018-3896 \\ Олександра ДУДУКАЛОВА, \\ a.duducalova@gmail.com \\ Berdiansk State Pedagogical \\ University \\ 4 SchmidtaSt., Berdiansk, \\ Zaporizhzhia region, 71100 \\ Original manuscript received: January 17, 2020 \\ Revised manuscript accepted: February 11, 2020
}

\begin{abstract}
In the article there have been theoretically grounded methodological approaches of forming the readiness of future economic profile's engineers-teachers for professional activity: conceptual (systemic, synergetic, competence) and specific (integrative, task and creative). There have been revealed the essence of methodological approaches and there have been characterized principles which reflect requirements for their using and provide the functioning the process of forming the readiness of future economic profile's engineers-teachers for professional activity. On the example of systemic approach there have been formed ways of realization of methodological approaches in the real educational process of higher educational establishments. On the basis of the systemic approach there have been defined a number of actions oriented to the development of the model of forming the readiness of future economic profile's engineers-teachers for professional activity, determination of general systemic properties and qualitative features of its parts. Thus, with the help of systemic approach there have been defines the purpose and tasks of educational, independent and practically-oriented activity of higher education applicants in accordance with curriculum and program of HEA (target component); methods of stimulating the positive motivation of higher education applicants (motivational component) have been selected; there have been defined the structure and content of subject and interdisciplinary knowledge, adequate the main functions which realize engineers-teachers in professional activity in the innovational context, there have been defined corresponding to the curriculum disciplines (content component); there have been determined forms, methods, techniques and means of educational, independent and practicallyoriented activity of future economic profile's engineers-teachers and there have been characterized criteria of corresponding displays of knowledge, skills and abilities (operational and activity component); there have been provided the effective control and self-control over the level of academic and personality achievements of higher education applicants (controlregulative component); the quality diagnostics and self-diagnostics of the level of academic and personal achievements of future economic profile's engineers-teachers have been provided (evaluation and effective component).
\end{abstract}

Key words: methodological approaches, future engineers-teachers, economic profile, professional activity. 
Вступ. Питання профресійної підготовки фрахівців, зокрема економічного профрілю, яке відповідає вимогам європейського освітнього простору, є одним із найактуальніших у сучасній професійній освіті. Це означає якісне оновлення змісту та форм організації навчання майбутніх фрахівців економічного профрілю, перегляд та переосмислення багатьох усталених традицій, внесення доповнень та коректив у систему вітчизняної профресійної освіти шляхом урахування інноваційних тенденцій.

Саме освіта повинна забезпечувати підготовку фрахівців, здатних до професійного розвитку та творчої праці. Ці положення спрямовують працівників освіти і науковців на пошуки нових шляхів реалізації освітніх, виховних і розвивальних цілей закладів вищої освіти, зокрема забезпечення особистісного розвитку людини згідно з ії індивідуальними задатками, здібностями, потребами на основі навчання впродовж життя (Про національну стратегію розвитку освіти в Україні на період до 2021 року, 2013). Продовження цих орієнтирів знайшло своє місце у наказі МОН України "Про затвердження Концепції розвитку педагогічної освіти" (2018) як подолання проблеми зниження якості освіти, зумовлене неспроможністю певної частини педагогічних працівників та здобувачів педагогічної освіти до опанування та практичного використання новітніх методик (технологій) навчання, виховання та розвитку. У концепції наголошується на вдосконаленні системи педагогічної освіти для створення бази підготовки педагогічних працівників нової генерації та розробленні сучасної моделі педагогічної профресії в контексті потреб суспільства, перспектив розвитку національної економіки та глобальних технологічних змін.

Закон «Про освіту» (2017) акцентує увагу на тому, що метою освіти в загальному сенсі, є всебічний розвиток людини як особистості та найвищої цінності суспільства, їі талантів, інтелектуальних, творчих i фрізичних здібностей; формування цінностей і необхідних для успішної самореалізації компетентностей; виховання відповідальних громадян, які здатні до свідомого суспільного вибору та спрямування своєї діяльності на користь іншим людям і суспільству; збагачення на цій основі інтелектуального, економічного, творчого, культурного потенціалу українського народу, підвищення освітнього рівня громадян задля забезпечення сталого розвитку України та її європейського вибору. Так, вища освіта зорієнтована на здобуття особою високого рівня наукових та творчих мистецьких, професійних і загальних компетентностей, необхідних для діяльності за певною спеціальністю чи галуззю знань.

У законодавчих та нормативно-правових актах, зокрема, у Законі України “Про вищу освіту" (2014) зазначено, що якість вищої освіти - це сукупність якостей особи, що відображає її професійну готовність, ціннісну орієнтацію, соціальну спрямованість і зумовлює здатність задовольняти як особисті духовні і матеріальні потреби, так і потреби суспільства. Отже, якість професійної підготовки - це характеристика фахівця, яка значною мірою забезпечує його успішну професійну діяльність у сучасному світі 3 глобалізованою економікою. Тому, основним завданням перед закладом вищої освіти в умовах сьогодення $€$ 
забезпечення необхідного рівня підготовки фахівців, здатних до ефективної професійної діяльності, швидкої адаптації, які володіють сучасними технологіями своєї спеціальності, уміннями використовувати отримані знання і навички в процесі вирішення швидкозмінних професійних завдань.

Підвищення ефективності функціонування економічної системи в Україні зумовлює потребу суспільства в інженерах-педагогах економічного профілю, які відповідатимуть вимогам розвитку фахового середовища в професійному та особистісному аспектах.

Теоретико-методологічну основу дослідження становлять напрацювання педагогічної науки щодо підготовки майбутніх інженерівпедагогів до професійної діяльності (І. Бендера, Н. Брюханова, Р. Горбатюк, Є. Громов, С. Гура, Р. Гуревич, С. Демченко, І. Каньковський, О. Коваленко, М. Лазарєв, В. Лобунець, Н. Ничкало та ін.); використання методологічних підходів у професійній освіті: системний підхід (В. Безрукова, В. Беспалько, Н. Брюханова, І. Васильєв, В. Гінецинський, Л. Гур'є, В. Докучаєва, І. Ісаєв, О. Заїр-Бек, С. Маркова, Д. Новиков, В. Сєриков, В. Юдін, Н. Яковлєва та ін.); синергетичний підхід (О. Бочкарьов, В. Виненко, С. Клепко, В. Кушнір, В. Маткін, Л. Сурчалова, Ю. Талагаєв, М. Федорова та ін.); компетентнісний підхід (В. Байденко, Н. Бібік, О. Дубасенюк, В. Захарченко, С. Калашнікова,

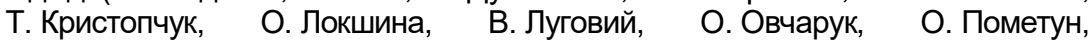
Ю. Рашкевич, Ж. Таланова, В. Шадриков та ін.); творчий підхід (В. Галузинський, М. Євтух, Н. Кічук, П. Кравчук, С. Омельченко, С. Сисоєва, Т. Сущенко та ін.); інтегративний підхід (С. Гончаренко, Р. Гуревич, Л. Дольнікова, В. Загвязинський, І. Козловська, Д. Коломієць, Ю. Мальований В. Сєріков, Я. Собко, Т.Якимович та ін.); задачний підхід (Г. Балл, Ю. Кравченко, Т. Новацький, Л. Спірін та ін.)

Однак змінні умови праці майбутніх інженерів-педагогів економічного профілю вимагають новітніх підходів до їхньої професійної підготовки.

Метою статті $€$ теоретичне обґрунтування методологічних підходів формування готовності майбутніх інженерів-педагогів до професійної діяльності.

Для досягнення мети сорормульовані такі завдання:

- розкрити сутність методологічних підходів та охарактеризувати принципи, які відображають вимоги до їх використання та забезпечують функціонування процесу формування готовності майбутніх інженерівпедагогів економічного профілю до професійної діяльності;

- на прикладі системного підходу сорормулювати шляхи реалізації методологічних підходів у реальному освітньому процесі закладів вищої освіти.

Методи та методики дослідження. Для досягнення мети, розв'язання завдань використано сукупність взаємопов'язаних теоретичних методів дослідження, як-то: аналіз, синтез, узагальнення та систематизація науково-теоретичних положень щодо виявлення стану дослідження проблеми формування готовності майбутніх інженерівпедагогів економічного профілю до професійної діяльності та обґрунтування методологічних засад означеного процесу.

Результати та дискусії. Теоретико-методологічну основу 
дослідження становлять провідні ідеї студентоцентризму як підґрунтя створення освітнього середовища, що передбачає забезпечення умов для реалізації потенціалу майбутніх інженерів-педагогів економічного профрілю до професійної діяльності в інноваційному контексті.

Визначаючи методологічні підходи та принципи формування готовності майбутніх інженерів-педагогів економічного профрілю до професійної діяльності, ми виходимо з того, що:

1. Принципи відображають ті суттєві характеристики, які відповідають за правильне функціонування системи, без котрих вона не виконувала б свого призначення (Философский словарь).

2. Підхід вказує на думку, з позиції якої розглядається об'єкт, та відображає сукупність способів, прийомів розгляду чого-небудь, впливу на кого-, що-небудь, ставлення до кого-, чого-небудь (Словник української мови, 1979); сукупність єдиноспрямованих за змістом принципів і методів, які не виходять за рамки підходу.

Проведене дослідження дозволило визначити основні методологічні підходи формування готовності майбутніх інженерівпедагогів економічного профілю до професійної діяльності: концептуальні (системний, синергетичний, компетентнісний) та специфічні (інтеграційний, задачний та творчий), зважаючи на особливості профресійної діяльності інженера-педагога економічного профілю.

Український педагогічний словник дає таке визначення: "Система - це комплекс елементів, що знаходяться у взаємодії, це різноманіття об’єктів разом з відношеннями між об'єктами та їх атрибутами". Системний підхід трактується як "напрям у спеціальній методології науки, завданням якого $€$ розробка методів дослідження й конструювання складних за організацією об'єктів як систем. Системний підхід у педагогіці спрямований на розкриття цілісності педагогічних об'єктів, виявлення в них різноманітних типів зв'язку та зведення їх у єдину теоретичну картину» (Гончаренко, 1997).

Формування готовності майбутніх інженерів-педагогів економічного профілю до професійної діяльності на засадах системного підходу базується на таких принципах: принцип багатоплановості, який полягає у тому, що будь-який об'єкт (система, процес, ситуація) розглядається в декількох планах, аспектах; принцип багатомірності полягає в тому, що будь-який складний об'єкт (система, процес, ситуація) характеризується великою сукупністю властивостей, які об'єднані в групи, кожна з яких описує ті чи інші його особливості; принцип ієрархічності полягає в тому, що вивчення складних об'єктів має базуватися на уявленні про ієрархічність їхньої структури, а саме на уявленні про розміщення частин або елементів цілого в порядку від вищого до нижчого; ієрархічну структуру мають не тільки моделі складу системи (системи - підсистеми - елементи), а також властивості якості цих систем та критерії, що використовуються для їх оцінки; принцип різнопорядковості властивостей полягає в тому, що ієрархічність будови системи та її властивостей породжує закономірності різного порядку; одні закономірності притаманні всім рівням ієрархії, усій системі, інші належать тільки деякій групі рівнів; треті - тільки елементам 
одного рівня, а четверті - тільки для окремих елементів одного рівня; принцип динамічності полягає в розгляданні об'єктів у їх розвитку на всіх етапах життєвого циклу.

Погоджуючись з Л.Гур'є, зазначені вище принципи доповнюємо ще такими: принцип людських пріоритетів, який орієнтує на людину - учасника підсистем, процесів або ситуацій; принцип діагностованості, що передбачає організацію постійного зворотного зв'язку, реалізацію вимірювального інструментарію, моніторинг функціонування системи на практиці (Гурье, 2004); принцип відповідності, тобто узгодженості між складниками формування готовності майбутніх інженерів-педагогів до професійної діяльності (наприклад, між професійними вимогами до інженерів-педагогів економічного профілю та змістом їхньої професійної підготовки).

Згідно із загальною теорією систем доцільним вважаємо виділення трьох аспектів реалізації системного підходу: функціонального, елементного та організаційного. Функціональний аспект вивчає та визначає коло функцій, які повинна виконувати система і відповідні підсистеми. Функціональні підсистеми, що складаються 3 функцій однакової цільової спрямованості, визначають коло завдань та формулюють логіку дії системи. Елементний аспект передбачає дослідження об'єкта (системи, процесу, ситуації) і встановлення його елементного складу. Організаційний аспект встановлює структуру системи (процесу формування готовності), визначає та реалізує завдання відповідно до функціонального призначення.

Системний підхід до організації освітнього процесу включає в себе: аналіз вихідних умов (мети підготовки, складу студентських груп, змісту програми курсу тощо); розробку системи методичних матеріалів та технологію їх використання 3 наступною перевіркою і внесенням необхідних коректив; заключну перевірку й оцінку системи. Системний підхід дозволяє визначити перспективи професійної підготовки, її основні взаємодіючі компоненти з урахуванням провідних тенденцій суспільного розвитку; реальні потреби і можливості суб'єктів підготовки, координацію і субординацію таких великих систем, як освіта, наука і техніка; формування нової людини як громадянина, особистості творчого педагогічного працівника і громадського діяча.

Системний підхід відображає не тільки кількісне, а й якісне зростання освіти взагалі, оскільки дає можливість прогнозувати освітні процеси з урахуванням вимог суспільства до освіти, якісних зрушень у науці, змісті та методах освіти на всіх їі рівнях (Шабанова, 2014).

Синергетичний підхід дає можливість розглянути освітній процес як систему з позиції відкритості, співтворчості та орієнтації на саморозвиток, сприяє розв'язанню протиріч, що виникають на різних рівнях освіти. 3 урахуванням синергетичного підходу фоормування готовності майбутніх інженерів-педагогів економічного профрілю до професійної діяльності має бути відкритою системою, тобто складатися 3 підсистем, між якими відбувається постійний обмін інформацією; забезпечувати перехід від управління до самоуправління, від розвитку під 
впливом зовнішніх фракторів до саморозвитку під впливом внутрішніх чинників освітнього середовища.

3 позиції синергетичного підходу виокремлюється низка фундаментальних синергетичних принципів організації освітньої системи: принцип незамкнутості, відкритості педагогічної системи зовнішньому середовищу; принцип самоорганізації та цілісності педагогічної системи; атракторність та гомеостатичність педагогічної системи; принципи нестійкості, біфуркаційності (крапки біфуркації), фрлуктуаційності, динамічної ієрархічності, педагогічної системи, її відкритість до надмалої дії; принципи адитивності (ціле більше частин), емерджентності (наявність нових системних якостей системи, які не $є$ сумою якостей її елементів), когерентності, нелінійності, ієрархічності освітньої системи; імовірнісний, надситуативний, самоактуалізаційний, самодетермінований характер освітнього процесу; принцип спостереження; принцип синергізації педагогічної системи (Вознюк, 2008).

Застосування компетентнісного підходу дозволяє відображати результати освіти в цілісному вигляді через систему ознак готовності майбутнього фахівця до виконання тієї чи іншої діяльності і, таким чином, ефективно моделювати цілі та результати професійної підготовки за допомогою виражених через компетенції норм ії якості. У зміст освіти включаються дисципліни, що фрормують більшою мірою компетентність у контексті майбутньої професійної діяльності, яка має міждисциплінарний, інтегрований характер, що дозволяє готувати випускників до діяльності в динамічно мінливих умовах професійного середовища.

Реалізація компетентнісного підходу у формуванні готовності майбутніх інженерів-педагогів економічного профілю до професійної діяльності базується на таких принципах: взаємозв'язок з гуманізацією освітнього процесу (саморозвиток, самореалізація); міждисциплінарність та інтегративність (єдність змістово-технологічного забезпечення процесу навчання); діагностичність (застосування різнорівневого підходу до оцінки результатів); як домінувальний - принцип студентоцентризму.

Творчий підхід формування готовності майбутніх інженерів-педагогів до професійної діяльності зорієнтований на оригінальність та високоефективність організації освітнього процесу, основними принципами якого є: принцип взаємозумовленості освіти і творчого розвитку особистості, в основі якого $є$ розуміння будь-якого навчання як джерела нового в психічному розвитку особистості; принцип самоорганізації, що відображає специфіку управління процесом формування творчої особистості й реалізації її творчого потенціалу, зумовлену особливостями управління нелінійними системами; принцип узгодження розвитку здобувачів вищої освіти з власними тенденціями розвитку шляхом збудження й ініціювання творчої активності, враховуючи, що при цьому управління повинно бути непомітним, мінімальним за своїм зовнішнім впливом і здійснюватися опосередкованими методами.

Задачний підхід формування готовності майбутніх інженерівпедагогів економічного профілю до професійної діяльності дає можливість посилити проблемну подачу теоретичного навчального 
матеріалу під час лекцій, спонукає студентів до роздумів, творчого пошуку інформації, самостійних висновків, узагальнень. Проблемні питання та проблемні практичні завдання сприяють також розвитку професійної рефлексії майбутніх інженерів-педагогів.

Розв'язуючи професійні задачі, майбутні інженери-педагоги навчаються поєднувати теоретичні знання з практичним застосуванням, бачити проблеми, трансформувати їх на задачі, ідентифікувати за рівнем складності, динаміки, ступенем визначеності, розуміти свій потенціал для їх розв'язання, шукати найкращі альтернативи розв'язку й отримувати гарантовано продуктивний результат. Тобто цей підхід дозволяє молодим фахівцям на виході з закладу вищої освіти бути професійно спроможним розв'язувати різні види і типи професійних задач.

Оскільки підготовка фахівців у закладах вищої освіти передбачає формування базових професійних компетентностей, то, безумовно, задачний підхід має відповідати: по-перше, видам і змісту професійних компетентностей, що утворюють цілі підготовки спеціалістів до професійної діяльності; по-друге, умовам здійснення професійної діяльності, тобто відображати реальні ситуації та проблеми, з якими матиме справу майбутні інженери-педагоги економічного профілю; потретє, дидактичному принципу навчання - поступовому засвоєнню професійних дій, спрямованих на розв'язання професійних задач. Використання задачного підходу наближає майбутнього інженерапедагога до реальної професійної діяльності (Буркова, 2015).

Інтегративний підхід в освіті забезпечує інтеграцію змісту освіти, тобто доцільне об'єднання його елементів у цілісність, коли результатом інтегративного підходу в педагогіці можуть бути цілісність знань різних рівнів - цілісність знань про дійсність; про природу з тієї чи іншої освітньої галузі, предмета, курсу, розділу, теми (Енциклопедія освіти, 2008). Відтак, інтеграція може розумітися як інтегративний процес, що веде до інтегративного продукту, коли досягається новий рівень системної цілісності об'єктів, що виявляють системні властивості цілого.

Інтегративний підхід передбачає поєднання всіх ланок освітнього процесу в дидактичну систему, що дозволяє майбутнім інженерампедагогам економічного профілю отримати комплекс умінь та знань, який можна творчо використовувати в професійній діяльності. Він відрізняється від інших підходів тим, що зв'язки між знаннями встановлюються не в навчальних програмах, а навпаки, вони укладаються, виходячи з реальних зв'язків між явищами, предметами чи поняттями (Бібік, 2014).

У межах дослідження інтегративний підхід до професійної підготовки майбутніх інженерів-педагогів економічного профілю визначався як сукупність форм і методів, що характеризують процес і результат формування такої інтегративної якості особистості фахівця, як готовність до професійної діяльності.

Визначені методологічні підходи формування майбутніх інженерівпедагогів економічного профілю до професійної діяльності стали основою для розробки моделі означеного процесу. Так, на засадах системного підходу було 
окреслено мету і завдання навчальної, самостійної та практично-зорієнтованої діяльностей здобувачів вищої освіти відповідно до навчального плану та програм ЗВО (цільовий складник); обрано методи стимулювання позитивної мотивації здобувачів вищої освіти (мотиваційний складник); визначено структуру та зміст предметних та міждисциплінарних знань, адекватних основним фрункціям, що реалізують інженери-педагоги в професійній діяльності в інноваційному контексті; встановлено відповідні до навчального плану дисципліни (змістовий складник); обрано фрорми, методи, прийоми і засоби навчальної, самостійної та практично зорієнтованої діяльностей майбутніх інженерів-педагогів економічного профрілю та схарактеризовано критерії відповідних виявів знань, умінь, навичок (операційно-діяльнісний складник); забезпечено дієвий контроль та самоконтроль за рівнем академічних і особистісних досягнень здобувачів вищої освіти (контрольно-регулювальний складник); забезпечено якісну діагностику та самодіагностику рівня академічних та особистісних досягнень майбутніх інженерів-педагогів економічного профілю (оцінно-результативний складник).

Висновки. На основі аналізу науково-теоретичних положень виявлено потребу в переосмисленні методологічних підходів та їх ролі у фрормуванні готовності майбутніх інженерів-педагогів економічного профрілю до профресійної діяльності в змінних умовах праці. Проведене дослідження дозволило визначити основні методологічні підходи фрормування готовності майбутніх інженерів-педагогів економічного профрілю до профресійної діяльності: концептуальні (системний, синергетичний, компетентнісний) та специфічні (інтеграційний, задачний та творчий), зважаючи на особливості профресійної діяльності інженера-педагога економічного профілю. Теоретично обґрунтовано можливості використання системного підходу в реальному освітньому процесі через низку дій зорієнтованих на розробку моделі формування готовності майбутніх інженерів-педагогів економічного профілю до професійної діяльності, визначення загальних системних властивостей та якісних характеристик її складників.

Перспективи подальших пошуків у напряму дослідження полягають у реалізації означених методологічних підходів у процесі профресійної підготовки майбутніх інженерів-педагогів економічного профілю.

\section{Література}

1. БібікГ.В.Міждисциплінарна інтеграція як основа якісної математичної освіти майбутніх учителів фрізики. Педагогічні науки. Вип. 66. Херсон : ХДУ, 2014. C. 247-253.

2. БурковаЛ. Задачний підхід у підготовці фахівців соціономічних професій: типи задач та особливості їх розв'язання. Педагогіка. 2(2). 2015. С. 11-15

3. Вознюк О.В. Розвиток вітчизняної педагогічної думки: синергетичний підхід (др. пол. XX ст.). Навчально-методичний посібник. Житомир: Вид-во ЖДУ, 2008. 150 с.

4. Гончаренко С. У. Український педагогічний словник. К.: Либідь, 1997. 376 с.

5. ГурьеЛ.И. Проектирование педагогических систем: учеб. пособ. Казань, 2004. 212 с.

6. Енциклопедія освіти / [гол. редактор В. Г. Кремень] / Акад. пед. наук України. К.: Юрінком Інтер, 2008. С. 356.

7. Про затвердження Концепції розвитку педагогічної освіти : наказ МОН 
України № 776 від 16.07.2018 p . URL: https://mon.gov.ua/ua/npa/prozatverdzhennya-koncepciyi-rozvitku-pedagogichnoyi-osviti (дата звернення: 05.03.20)

8. Про вищу освіту : закон України № 1556-VII від 01.07.2014. URL : http://vnz.org.ua/zakonodavstvo/111-zakon-ukrayiny-pro-vyschu-osvit (дата звернення: 05.03.2020)

9. Про Національну стратегію розвитку освіти в Україні на період до 2021 року : указ Президента України № 344/2013 від 25.06. 2013 p. URL: president.gov.ua (дата звернення: 05.03.20)

10. Про освіту: закон України №38-39 від 05.09.2017p. URL: http://zakon3.rada.gov.ua/laws/show/2145-19 (дата звернення: 05.03.2020)

11. Словник української мови: в 11 томах. Том 10. 1979. С. 441. URL: http://sum.in.ua/p/10/441/2 (дата звернення: 05.03.2020)

12. Философский словарь: крупнейший сборник онлайн-словарей / С. Радионова, С Савелова. URL: http://www.onlinedics.ru/slovar/fil/p/ proektirovanie.html, http://www.onlinedics.ru/slovar/fil/p/proekt.html (дата звернення: 05.03.2020)

13. Шабанова Ю. О. Системний підхід у вищій школі: підруч. Дніпропетровськ, 2014. 120 с.

\section{References}

1.Bibik G. V. Mizhdy`scy plinarna integraciya yak osnova yakisnoyi matematy 'chnoyi osvity' majbutnix uchy`teliv fizy`ky`. Pedagogichni nauky`. Vy`p. 66. Xerson: XDU, 2014. S. 247-253.

2. Burkova L. Zadachny j pidxid u pidgotovci faxivciv socionomichny`x profesij: ty 'py`zadach ta osobly 'vosti yix rozv'yazannya. Pedagogika. 2(2). 2015. S. 11-15

3.Voznyuk O.V. Rozvy'tok vitchy`znyanoyi pedagogichnoyi dumky: sy`nergety`chny`j pidxid (dr. pol. XX st.). Navchal’no-metody`chny`j posibny`k. Zhy`tomy'r: Vy'd-vo ZhDU, 2008. $150 \mathrm{~s}$.

4. Goncharenko S. U. Ukrayins 'ky’ j pedagogichny’j slovny’k. K.: Ly’bid', 1997. 376 s.

5.Gur'e L. Y'. Proekty'rovany'e pedagogy'chesky'x sy'stem: ucheb. posob. Kazan`, 2004.212 s.

6. Ency`klopediya osvity` / [gol. redaktor V. G. Kremen`] / Akad. ped. nauk Ukrayiny' K.: Yurinkom Inter, 2008. S. 356.

7.Pro zatverdzhennya Koncepciyi rozvy`tku pedagogichnoyi osvity` : nakaz MON Ukrayiny` \# 776 vid 16.07.2018 r . URL: https://mon.gov.ua/ua/npa/prozatverdzhennya-koncepciyi-rozvitku-pedagogichnoyi-osviti (data zvernennya: 05.03.20)

8. Pro vy`shhu osvitu : zakon Ukrayiny №1556-VII vid 01.07.2014. URL : http://vnz.org.ua/zakonodavstvo/111-zakon-ukrayiny-pro-vyschu-osvit (data zvernennya: 05.03.2020)

9. Pro Nacional 'nu strategiyu rozvy`tku osvity` v Ukrayini na period do 2021 roku : ukaz Prezy`denta Ukrayiny` \# 344/2013 vid 25.06. 2013 r. URL: president.gov.ua (data zvernennya: 05.03.20)

10. Pro osvitu: zakon Ukrayiny №38-39 vid 05.09.2017r. URL: http://zakon3.rada.gov.ua/laws/show/2145-19 (data zvernennya: 05.03.2020)

11. Slovny`k ukrayins koyi movy`: v 11 tomax. Tom 10. 1979. S. 441. URL: http://sum.in.ua/p/10/441/2 (data zvernennya: 05.03.2020)

12. Fy’losofsky`j slovar’: krupnejshy`j sborny`k onlajn-slovarej / S. Rady`onova, S Savelova. URL: http://www.onlinedics.ru/slovar/fil/p/ proektirovanie.html, http://www.onlinedics.ru/slovar/fil/p/proekt.html (data zvernennya: 05.03.2020)

13. Shabanova Yu. O. Sy`stemny`j pidxid u vy`shhij shkoli: pidruch. Dnipropetrovs`k, 2014. 120 s. 


\section{АНОТАЦІЯ}

У статті теоретично обгрунтовано методологічні підходи фоормування готовності майбутніх інженерів-педагогів економічного профрілю до профресійної діяльності: концептуальні (системний, синергетичний, компетентнісний) та специфрічні (інтегративний, задачний та творчий). Розкрито сутність методологічних підходів та охарактеризовано принципи, які відображають вимоги до їх використання та забезпечують функціонування процесу формування готовності майбутніх інженерів-педагогів економічного профілю до профресійної діяльності. На прикладі системного підходу сформульовано шляхи реалізації методологічних підходів у реальному освітньому процесі закладів вищої освіти. Зазначено низку дій на основі системного підходу зорієнтованих на розробку моделі формування готовності майбутніх інженерів-педагогів економічного профрілю до професійної діяльності, визначення загальних властивостей та якісних характеристик їі складників. Так, за допомогою системного підходу окреслено мету і завдання навчальної, самостійної та практично-зорієнтованої діяльностей здобувачів вищої освіти відповідно до навчального плану та програм ЗВО (цільовий складник); обрано методи стимулювання позитивної мотивації здобувачів вищої освіти (мотиваційний складник); визначено структуру та зміст предметних та міждисциплінарних знань, адекватних основним функціям, що реалізують інженери-педагоги в профресійній діяльності в інноваційному контексті, обрано відповідні до навчального плану дисципліни (змістовий складник); обрано фрорми, методи, прийоми і засоби навчальної, самостійної та практично зорієнтованої діяльностей майбутніх інженерів-педагогів економічного профрілю та схарактеризовано критерії відповідних виявів знань, умінь, навичок (операційнодіяльнісний складник); забезпечено дієвий контроль та самоконтроль за рівнем академічних і особистісних досягнень здобувачів вищої освіти (контрольнорегулювальний складник); забезпечено якісну діагностику та самодіагностику рівня академічних та особистісних досягнень майбутніх інженерів-педагогів економічного профрілю (оцінно-результативний складник).

Ключові слова: методологічні підходи, майбутні інженери-педагоги, економічний профріль, професійна діяльність. 